\title{
Pengaruh Kepemimpinan, Iklim Organisasi, Motivasi, Dan Kepuasan Kerja, Terhadap Kinerja Guru Sekolah Dasar Negeri Gugus IV Kecamatan Tampan Kota Pekanbaru
}

\author{
Seniwati ${ }^{1}$, Sudarno ${ }^{2}$, Rini Fatmasari ${ }^{3}$ \\ Email: Seniwatiathaya4@gmail.com ${ }^{1}$, sdntalenta@yahoo.com ${ }^{2}$, riens@ecampus.ut.ac.id ${ }^{3}$ \\ Program Pasca sarjana Universitas Terbuka
}

Received: 13 August 2021; Revised: 02 October 2021; Accepted: 14 December 2021

DOI: http://dx.doi.org/10.37905/aksara.8.1.31-42.2022

\begin{abstract}
Abstrak
Kinerja guru Sekolah Dasar Negeri gugus IV Kecamatan Tampan Kota Pekanbaru masih relatif rendah, hal ini dipengaruhi oleh beberapa faktor diantaranya kepemimpinan, iklim organisasi, motivasi dan kepuasan kerja. Tujuan penelitian ini adalah untuk mengetahui dan menganalisis pengaruh kepemimpinan terhadap kinerja guru, iklim organisasi terhadap kinerja guru, motivasi terhadap kinerja guru dan kepuasan kerja terhadap kinerja guru. Penelitian ini merupakan penelitian kuantitatif dengan jumlah sampel 65 responden yang ditentukan berdasarkan Teknik sampling total. Variabel independen dalam penelitian ini adalah kepemimpinan, iklim organisasi, motivasi, dan kepuasan kerja sedangkan variabel dependen adalah kinerja guru. Pengukuran variabel menggunakan skala Likert yang diisi berdasarkan presepsi guru. Analisa data menggunakan regresi linier berganda dengan bantuan SPSS versi 22. Berdasarkan pengujian, model dinyatakan memenuhi asumsi klasik dan uji kelayakan model, dan diperoleh persamaan regresi linier berganda $Y=-0,036+0,257 X_{1}+0,019 X_{2}+0,106 X_{3}+0,290 X_{4}$. Hasil analisa secara parsial menunjukkan bahwa kepemimpinan, iklim organisasi, kepuasan kerja berpengaruh positif dan signifikan terhadap kinerja guru, sedangkan motivasi berpengaruh positif tetapi tidak signifikan terhadap kinerja guru. Secara simultan seluruh variable independen berpengaruh positif dan signifikan terhadap kinerja guru sebesar $76,4 \%$. Sisanya $23,6 \%$ dipengaruhi oleh faktor lain yang tidak dibahas dalam penelitian ini.
\end{abstract}

Kata kunci: Kepemimpinan, Iklim Organisasi, Motivasi, Kepuasan Kerja, Kinerja Guru.

\section{PENDAHULUAN}

Pendidikan menjadi elemen dasar pondasi untuk membangun segala aspek kehidupan, begitu pentingnya pendidikan ini, menjadikan pemerintah selalu berupaya untuk meningkatkan kualitas pendidikan dengan berbagai gebrakan-gebrakan. Berdasarkan UU No. 20 tahun 2003 tentang pendidikan Nasional, Indonesia memiliki tujuan pendidikan yang sangat mulia, bukan hanya membentuk dan mengembangkan karakter, kemampuan kognitif, dan kemampuan ketrampilan saja, tetapi juga jiwa religius, sehat, memiliki semangat yang tinggi, tangguh, bardaya saing, berahlak mulia, dan cinta tanah air. Tujuan pendidikan ini dapat dicapai apabila seluruh unsur pendidikan dapat bersinergi, terutama guru yang merupakan pilar utama dalam menentukan tercapainya tujuan pendidikan.

Kualitas pendidikan dapat dicapai aapabila guru memiliki kinerja yang tinggi. Kinerja guru ditentukan oleh beberapa faktor, secara umum faktor yang berasal dari dalam diri (internal) guru itu sendiri diantaranya faktor motivasi dan kepuasan kerja sedangkan faktor dari luar diri (eksternal) guru tersebut diantaranya dipengaruhi oleh faktor kepemimpinan dan iklim organisasi. Berdasarkan data pendahuluan dari angket yang disebar sebagai uji data awal ditemukan bahwa pemimpin belum sepenuhnya menjalankan fungsinya sebagai pemimpin, hasil angket yang diperoleh hanya $20 \%$ pemimpin menjalankan fungsinya, sedangkan uji pendahuluan untuk iklim organisasi 
diperoleh sebesar $44 \%$ yang berarti iklim organisasi belumlah kondusif. Pernyataan ini diperkuat oleh data Dinas Pendidikan Kota Pekanbaru.

Tabel 1. Rekapitulasi Kinerja Guru SDN Gugus IV Kecamatan Tampan Kota Pekanbaru

\begin{tabular}{|l|l|l|l|l|l|l|l|}
\hline No & $\begin{array}{l}\text { Nama } \\
\text { Sekolah }\end{array}$ & $\begin{array}{l}\text { Jumlah } \\
\text { Guru }\end{array}$ & RPP & $\begin{array}{l}\text { Progra } \\
\mathrm{m}\end{array}$ & $\begin{array}{l}\text { Melakuka } \\
\text { n Evaluasi }\end{array}$ & $\begin{array}{l}\text { Penilaian } \\
\text { Belajar }\end{array}$ & BP \\
\hline 1 & SDN 110 & 15 & 13 & 10 & 14 & 12 & 10 \\
\hline 2 & SDN 165 & 15 & 10 & 12 & 12 & 10 & 9 \\
\hline 3 & SDN 176 & 17 & 11 & 10 & 11 & 6 & 10 \\
\hline 4 & SDN 187 & 18 & 10 & 9 & 11 & 7 & 11 \\
\hline & Jumlah & 65 & 44 & 41 & 48 & 35 & 40 \\
\hline & Rata-rata (\%) & & 67,69 & 63,07 & 75,00 & 59,32 & 61,54 \\
\hline
\end{tabular}

Sumber: Data Sekunder 2020

Berdasarkan tabel 1.1 masih terdapat guru yang tidak membuat RPP sebanyak $32,31 \%$, yang tidak membuat program pengajaran sebanyak $36,93 \%$, terdapat $25 \%$ guru yang tidak melakukan evaluasi, masih banyak guru yang tidak melakukan penilaian hasil belajar yaitu sebesar 40, 68\% serta tidak melaksanakan bimbingan konseling sebesar 38,46\%. Dari data yang diperoleh dapat dikatakan bahwa kinerja guru Sekolah Dasar Negeri gugus IV Kecamatan Tampan Kota Pekanbaru belum maksimal. Data-data ini merupakan fakta yang ditemukan di lapangan yang relevan dengan penelitian sebelumnya yang telah dilakukan oleh beberapa peneliti yaitu: Saragih (2015) yang menemukan bahwa motivasi berpengaruh positif dan signifikan terhadap kinerja, Purwaningrum dan Sudirjo (2016) dari hasil penelitiannya menyatakan bahwa kepemimpinan mempengaruhi kinerja secara positif dan signifikan begitu juga kepuasan kerja berpengaruh positif dan signifikan terhadap kinerja guru. Englasari (2017) menemukan bahwa motivasi kerja berpengaruh positif dan signifikan terhadap kinerja guru. Wardoyo (2018) menemukan hasil penelitiannya bahwa iklim organisasi berpengaruh positif dan signifikan terhadap kinerja guru begitu juga motivasi berpengaruh positif dan signifikan terhadap kinerja guru. Markonah dan Sunarto (2018), menemukan bahwa motivasi berpengaruh tidak signifikan terhadap kinerja guru. Husna (2019) mengungkap bahwa iklim organisasi mempengaruhi kinerja secara positif tetapi tidak signifikan sedangkan kepemimpinan berpengaruh positif dan signifikan terhadap kinerja. Putra, dkk. (2019) menemukan dalam penelitiannya yaitu kepemimpinan berpengaruh positif dan signifikan terhadap kinerja dan motivasi juga berpengaruh positif dan signifikan terhadap kinerja. Fatati dkk, (2019) menemukan hasil risetnya bahwa kepuasan kerja berpengaruh positif dan signifikan terhadap kinerja guru.

Berdasarkan fenomena yang ditemukan dan adanya GAP research hasil penelitian terdahulu, tertarik dilakukannya penelitian "Pengaruh kepemimpinaan, iklim organisasi, motivasi dan kepuasan kerja terhadaap kinerja guru Sekolah Dasar Negeri gugus IV Kecamatan Tampan Kota Pekanbaru". Permasalahan dalam penelitian ini dapat dirumuskan, apakah terdapat pengaruh kepemimpinan, iklim organisasi, motivasi, dan kepuasan kerja baik secara persial maupun simultan terhadap kinerja guru Sekolah Dasar Negeri Gugus IV Kecamatan Tampan Kota Pekanbaru?

Kepemimpinan merupakan sekumpulan kemampuan untuk dapat mempengaruhi, menggerakkan, dan melakukan dengan sebaik-baaik mungkin agar 
mencapai hasil yang berkualitas sesuai tujuan yang telah ditetapkan Kepemimpinan merupakan elemen penting dalam mencapai kerja produktif dalam rangka meningkatkan kualitas pekerjaan yang berdampak kepada kinerja seseorang (Muizu et al, 2019). Steinberg \& Garrett (2016) menyatakan bahwa organisasi harus dijalankan dengan menggunakan prinsip-prinsip kepemimpinan, agar yang diupayakan dapat menghasilkan sebuah kinerja yang berkualitas efektif dan efesien. Teori tersebut sangat relevan dengan penelitian yang dilakukan oleh Purwaningrum \& Sudirjoo (2016), bahwa kepemimpinan berpengaruh positif terhadap kinerja. Iklim organisasi merupakan keadaan situasi dan kondisi organisasi yang dirasakan oleh individu yang dapat mempengaruhi kinerja (Davis \& Newstrom dalam Suwantono (2019), Fadhli (2017), Wirawan dalam Triastuti (2018)). Hal ini relevan dengan penelitian yang dilakukan oleh Wardoyo (2018) yang menemukan bahwa iklim organisasi berpengaruh positif dan signifikan terhadap kinerja guru.

Motivasi guru merupakan daya pendorong untuk melakukan tugas dan tanggung jawab sebaik mungkin dalam memenuhi kebutuhan baik individu maupun organisasi dalam rangka meningkatkan kinerja guru (Dornyei \& Ushioda, Williams \& Burden, dalam Han \& Yin (2016), Robbins dalam Maeni (2018), Han \& Yin (2016)). Teori ini didukung oleh hasil penelitian yang dilakukan oleh Saragih (2015), Wardoyo (2018), Englasari (2019), Putra dkk (2019) yang menemukan bahwa motivasi berpengaruh positif dan signifikan terhadap kinerja guru.

Kepuasan kerja adalah ungkapan perasan guru terhadap segala sesuatu yang mendukung kerja dalam rangka peningkatan kinerja guru (Kamdron (2015), Raziq \& Maulabakhsh (2015)) Pernyataan ini sesuai dengan penelitian yang dilakukan oleh Purwaningrum dan Sudirjo (2016) dan juga Fatati dkk (2019), bahwa kepuasan kerja berpengaruh positif dan signifikan terhadap kinerja guru. Kinerja guru merupakan kemampuan mencapai hasil kerja (out put) baik kualitas maupun kuantitas, dengan tepat waktu sesuai ketentuan yang ditetapkan. Kinerja guru merupakan hasil kerjasama seluruh sumber daya yang ada dalam organisasi (sekolah) untuk melakukan tugas sebagai usaha dan upaya mencapai tujuan organisasi (Qodriah dan Muhsin, 2019). Berdasarkan teori yang menyatakan terdapatnya hubungan antar variabel, maka dapat diasumsikan bahwa terdapat pengaruh positif dan signifikan antara kepemimpinan, iklim organisasi, motivasi, dan kepuasan kerja terhadap kinerja. Hubungan antar variabel tersebut tergambar dalam kerangka berfikir gambar 1 . 


\section{Gambar 1. Kerangka pemikiran}

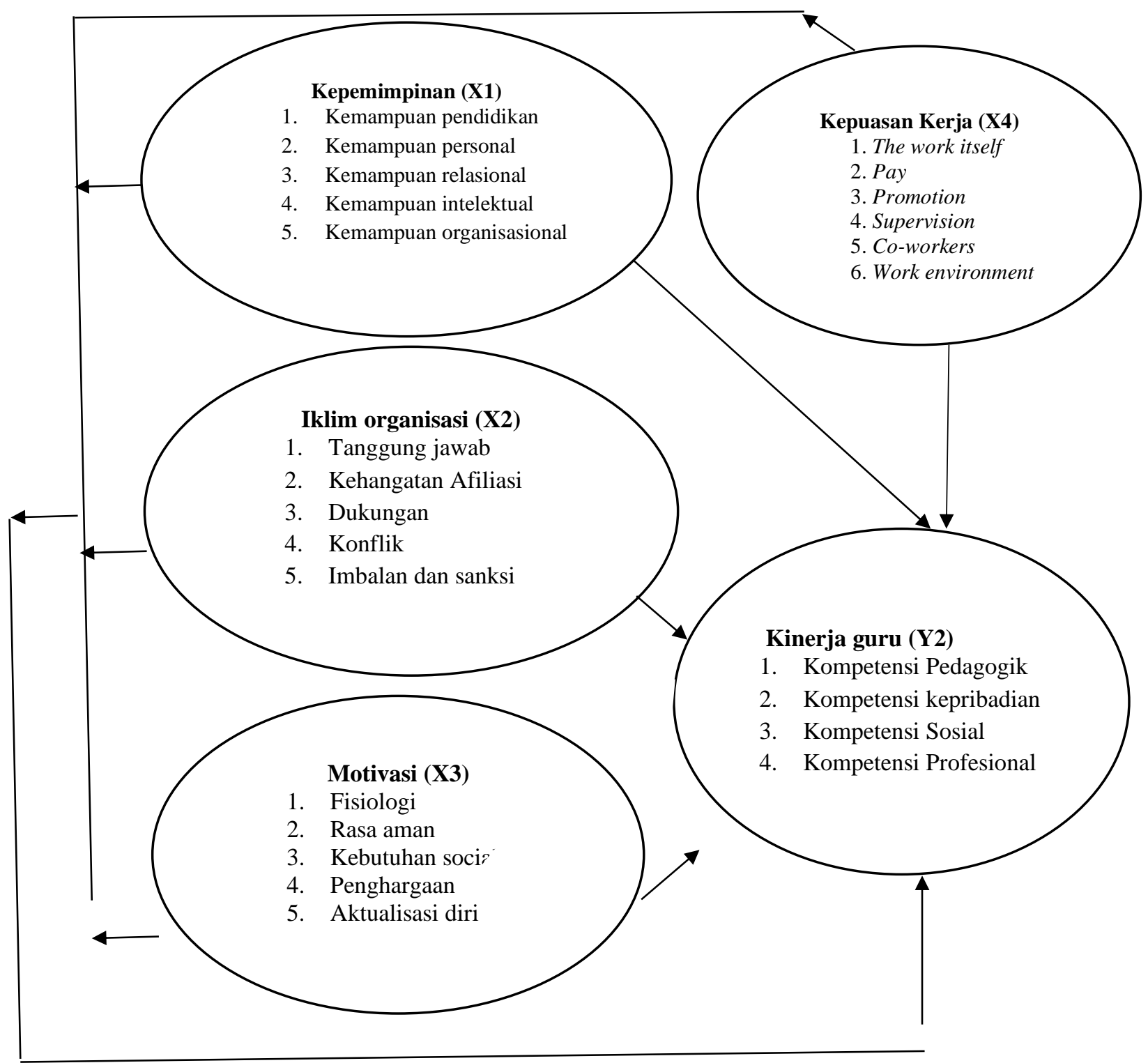

METODE PENELITIAN

Penelitian ini menggunakan pendekatan kuantitatif dengan metode analisa data Regresi Linier Berganda (Multiple Linear Regression) yang bertujuan untuk mengetahui dan menganalisa pengaruh dan besarnya pengaruh dari variabel bebas terhadap satu variabel terikat. Pengumpulan data penelitian menggunakan kuesioner skala Likert yang sudah divalidasi dan direliabilitasi dengan bantuan SPSS 22. Kuesioner penelitian ini terdiri dari 5 jenis instrumen sesuai variabel penelitian, yang seluruhnya diisi berdasarkan presepsi guru. Pengukuran variabel penelitian didasarkan pada dimensi yang ditetapkan dalam penelitian. Kinerja guru diukur menurut Permendiknas No. 19/2007, kepemimpinan diukur sesuai teori Duignan dalam Risamasu (2017). 
Iklim organisasi diukur berdasarkan teori Litwin \& Stringer dalam Kamuli (2012), motivasi diukur berdasarkan teori Maslow dalam Irawati, dkk (2019), dan kepuasan kerja diukur menurut teori Shabir \& Wei (2016).

Prosedur pengumpulan data diawali validasi konstruk oleh para ahli berikutnya pengembangan instrument berdasarkan kisi-kisi yang telah ditetapkan. Instrumen yang telah diuji kualitasnya dengan bantuan SPSS 22 dan dinyatakan layak untuk digunakan dalam penelitian selanjutnya disebar kepada sampel yang telah ditentukan. Data dikumpulkan, ditabulasi, kemudian dianalisa. Tahap analisa yaitu uji asumsi klasik yang mencakup uji normalitas, multikolonieritas, dan heteroskedastisitas, kemudian uji kelayakan model, yaitu pengujian model mencakup uji koefisien determinasi, uji statistik t, dan uji statistik F, selanjutnya analisa deskriptif, yaitu analisa berdasarkan karakteristik responden dan tanggapan responden terhadap variabel penelitian, tahap berikutnya yaitu uji hipotesis, yaitu proses analisa data untuk menguji hipotesis yang telah ditetapkan. Uji hipotesis mencakup uji parsial dan uji simultan, dan tahap terakhir menguji besarnya pengaruh variable bebas terhadap variable terikat, dengan melihat nilai Adjusted $R^{2}$.

\section{HASIL PENELITIAN DAN PEMBAHASAN}

\section{Analisa Deskriptif}

Berdasarkan karakteristik responden, responden didominasi oleh guru perempuan yaitu sebesar $78,5 \%$, berdasarkan usia didominasi oleh responden yang berusia diatas 40 tahun yaitu sebesar 64,6\%, sedangkan berdasarkan sertifikasi didominasi oleh responden bersertifikasi yaitu sebesar 89,2\%. Tanggapan responden berdasarkan variabel penelitian kinerja guru secara umum rata-rata tanggapan berada pada kategori cukup baik. Tanggapan responden berdasarkan variabel penelitian ratarata cukup baik, kecuali tanggapan responden pada variable kepemimpinan, berada pada kategori tidak baik.

\section{Uji Kualitas Data}

Uji validitas dilakukan dengan bantuan SPSS 22, dengan hasil uji dinyatakan bahwa seluruh pernyataan instrumen yang digunakan valid. Uji reliabilitas dilakukan dengan bantuan SPSS 22, yaitu melihat nilai Cronbach's alpha. Nilai Cronbach's alpha masing-masing variabel disajikan dalam tabel 2.

Tabel 2. Uji Reliabilitas Instrumen

\begin{tabular}{|l|l|l|l|l|}
\hline No & Variabel & Cronbach's Alpha & Nof Items & Keterangan \\
\hline 1 & Kepemimpinan & .928 & 30 & Reliabel \\
\hline 2 & Iklim Organisasi & .857 & 20 & Reliabel \\
\hline 3 & Motivasi & .897 & 21 & Reliabel \\
\hline 4 & Kepuasan Kerja & .940 & 28 & Reliabel \\
\hline 5 & Kinerja Guru & .924 & 30 & Reliabel \\
\hline
\end{tabular}

Sumber: Data Olahan SPSS 22

Menurut kriteria Nunnally dalam Ghozali (2018: 46) instrumen dinyatakan reliable jika nilai Cronbach's Alpha lebih besar dari 0,70. Dengan demikian maka instrumen yang digunakan dalam penelitian sangat reliabel. 
Berdasarkan pengujian asumsi klasik, penelitian ini sudah memenuhi uji normalitas (melihat histogram dimana kurva tidak menceng kekiri maupun kekanan, dan juga dapat dilihat dari P- P plot, dimana grafik menunjukkan bahwa titik-titik selalu mendekati garis diagonal), uji multikolonieritas (tidak terjadi gejala multikolonieritas, dmana nilai VIF $<10$ dan nilai tolerance $>0,1$ ), uji heteroskadastisitas (tidak terjadi heteroskedastisitas, dimana scatterplot menunjukkan bahwa titi-titik menyebar secara acak yang berada dibawah maupun diatas titik 0 pada sumbu $\mathrm{Y}$, sehingga dapat disimpulkan bahwa tidak terjadi heteroskedastisitas.

\section{Uji kelayakan model}

Model regresi linier berganda yang digunakan dalam penelitian ini dinyatakan memenuhi uji kelayakan, hal ini dibuktikan dengan nilai koefisien determinasi $R$ Square (dalam hal ini Adjusted $R$ Square) sebesar 76,4\%, nilai statistik F dimana nilai beta $\mathrm{b} 1 \neq$ $\mathrm{b} 2 \neq \mathrm{b} 3 \neq \mathrm{b} 4 \neq 0$ dan $\mathrm{F}$ hitung lebih besar dari $\mathrm{F}$ tabel., dan nilai statistik $\mathrm{t}$ dimana nilai beta $b i \neq 0$ dan thitung lebih besar dari t tabel.

\section{Uji Hipotesis}

\section{a. Uji parsial (Uji t)}

Uji t digunakan untuk mendeteksi seberapa jauh pengaruh satu variable bebas dalam menjelaskan variabel terikat secara individual (Ghojali, 2018: 98-99). Hasil uji disajikan dalam tabel 3.

Tabel 3. Uji t Pengaruh Variabel X terhadap Variabel Y

\begin{tabular}{|c|c|c|c|c|c|c|}
\hline \multirow{2}{*}{\multicolumn{2}{|c|}{ Model }} & \multicolumn{2}{|c|}{$\begin{array}{l}\text { Unstandardized } \\
\text { Coefficients }\end{array}$} & \multirow{2}{*}{\begin{tabular}{|l|l}
$\begin{array}{l}\text { Standardized } \\
\text { Coefficients }\end{array}$ \\
Beta
\end{tabular}} & \multirow[t]{2}{*}{$t$} & \multirow[t]{2}{*}{ Sig. } \\
\hline & & B & Std. Error & & & \\
\hline \multirow{5}{*}{1} & (Constant) & -.036 & .209 & & -.173 & .863 \\
\hline & Kepemimpinan_X1 & .257 & .086 & .263 & 2.998 & .004 \\
\hline & IklimOrganisasi X2 & .019 & .006 & .348 & 3.047 & .003 \\
\hline & Motivasi_X3 & .106 & .103 & .099 & 1.031 & .307 \\
\hline & Kepuasan_X4 & .290 & .070 & .332 & 4.154 & .000 \\
\hline
\end{tabular}

Sumber: Data Primer Olahan SPSS

Dari tabel 3, dapat dituliskan persamaan Regresi Linier berganda yaitu:

$Y=-0,036+0,257 X_{1}+0,019 X_{2}+0,106 X_{3}+0,290 X_{4}$

Berdasarkan tabel 3, dapat diuraikan pengaruh parsial masing-masing variabel sebagai berikut:

\section{Pengaruh Kepemimpinan (X1) terhadap Kinerja Guru (Y)}

Kepemimpinan berpengaruh positif dan signifikan terhadap kinerja guru, hal ini berarti bahwa kepemimpinan yang baik akan meningkatkan kinerja guru dan sebaliknya, jika kepemimpinan tidak baik, maka akan menurunkan kinerja guru. Hasil penelitian ini sejalan dengan hasil penelitian terdahulu yang dilakukan oleh Poerwaningrum \& Sudirjo (2016) dengan judul "Pengaruh Kepemimpinan, Budaya orgaanisasi, Komitmen Organisasi dan Kepuasan Kerja terhadap Kinerja Guru SD Hj. Isriati Baiturrahman I Semarang". Hasil temuan sejalan juga ditemukan dalam 
penelitian terdahulu yang dilakukan oleh Husna (2019) dan Putra, dkk (2019) yang menyatakan terdapat pengaruh positif dan signifikan kepemimpinan terhadap kinerja guru.

Bardasarkan hasil penelitian, tanggapan responden terhadap masing-masing pernyataan variabel penelitian, dapat disimpulkan bahwa kepemimpinan belum terlaksana dengan baik, Kepala Sekolah belum sepenuhnya memiliki kemampuan pendidikan, personal, relasional, intelektual, dan organisasional. Kepala Sekolah hendaknya terus mengasah kemampuan sebagai pemimpin terutama dalam hal memberikan perhatian kepada seluruh guru dengan adil, memiliki orientasi masa depan dalam memajukan komunitas sekolah secara adil, memiliki kepercayaan pada kemampuan guru dan juga potensi peserta didik, mampu mengtasi masalah dengan bijaksana, bersifat dewasa dan teladan serta mampu menciptakan iklim sekolah yang saling menghargai, saling percaya dan mendukung dalam mencapai tujuan bersama.

Kepemimpinan merupakan elemen penting dalam mencapai kerja produktif dalam rangka meningkatkan kualitas pekerjaan yang berdampak kepada kinerja seseorang (Muizu et al, 2019). Steinberg \& Garrett (2016) menyatakan bahwa organisasi harus dijalankan dengan menggunakan prinsip-prinsip kepemimpinan, agar yang diupayakan dapat menghasilkan sebuah kinerja yang berkualitas efektif dan efesien. Kepemimpinan Kepala Sekolah dapat terus ditingkatkan melalui kemampuan mempengaruhi dan menggerakkan seluruh potensi yang dimiliki sekolah. Menurut Charlote dan Duignan dalam Risamasu (2017) menyatakan bahwa keberhasilan Kepala Sekolah sebagai pemimpin pendidikan adalah pemimipin yang mampu memimpin dengan multi dimensi, yaitu dimensi kemampuan pendidikan, kepribadian (personality), kemampuan relasional, intelektual dan aspek organisasional. Berdasarkan hasil penelitian yang diperkuat penelitian terdahulu serta teori yang mendukung, maka Hal diterima.

\section{Pengaruh Iklim Organisasi (X2) terhadap Kinerja Guru (Y)}

Iklim organisasi berpengaruh positif dan signifikan terhadap kinerja guru. Hasil penelitian ini sejalan dengan hasil penelitian terdahulu yang dilakukan oleh Wardoyo (2018) dengan judul penelitian "Kontribusi Kepemimpinan transformasional, Iklim Organisasi, dan Motivasi berprestasi terhadap Kinerja Guru SD Negeri Gembongan, Kec. Sentolo, Kulon Progo" yang menyatakan bahwa terdapat pengaruh positif dan signifikan iklim organisasi terhadap kinerja guru. Bardasarkan hasil penelitian, tanggapan responden terhadap masing-masing pernyataan variabel iklim organisasi, dapat disimpulkan bahwa iklim organisasi di Sekolah Dasar Negeri gugus IV Kecamatan Tampan Kota Pekanbaru cukup baik. Kepala Sekolah dan seluruh warga sekolah hendaknya bahu-membahu agar iklim organisasi menjadi lebih baik, terutama dalam hal Kepala Sekolah memberikan perhatian dan peduli pada masalah yang dihadapi guru, meningkatkan kesetiakawanan dan saling membantu, para guru merasa bebas dan tidak takut untuk tidak menyetujui tindakan atasan apabila dirasa salah, prestasi yang diraih guru hendaknya mendapat penghaargaan, rasa dihargai dari atasan dan rekan kerja.

Iklim organisasi merupakan keadaan situasi dan kondisi organisasi yang dirasakan oleh individu yang dapat mempengaruhi kinerja (Davis \& Newstrom dalam Suwantono, Fadhli, Wirawan dalam Triastuti). Iklim organisasi yang kondusif 
melibatkan seluruh elemen dalam organisasi. Situasi yang kondusif dapat dicapai dengan adanya rasa tanggung jawab (Responsibility) seluruh anggota organisasi, saling mendukung (Support), rasa kekeluargaaan yang penuh kehangatan (Warmth), menghindari konflik (Conflict) dengan cara saling memahami, serta mendapat imbalan yang sesui dan sanksi apabila membuat kesalahan yang sifatnya membangun (Reward and Punishment) (Litwin \& Stringer, Houser dalam kamuli, 2012). Berdasarkan hasil penelitian yang diperkuat penelitian terdahulu serta teori yang mendukung, maka Ha2 diterima.

\section{Pengaruh Motivasi (X3) terhadap Kinerja Guru (Y)}

Motivasi berpengaruh positif tetapi tidak signifikan secara parsial terhadap kinerja guru. Hasil penelitian ini sejalan dengan hasil penelitian terdahulu yang dilakukan oleh Markonah dan Sunaryo (2018) dengan judul penelitian "Pengaruh motivasi dan kompetensi terhadap kinerja guru dimediasi komitmen organisasional (Studi Kasus Di SMA Negeri 1 Jakenan Kabupaten Pati) dan berbeda dengan penelitian Saragih (2015), penelitian Wardoyo (2018), Englasari (2019), dan Putra dkk (2019) yang menemukan bahwa motivasi berpengaruh positif dan signifikan terhadap kinerja guru. Tanggapan responden pada motivasi dinyatakan cukup baik, hal ini menunjukkan bahwa guru sudah memiliki motivasi dalam menjalankan tugas-tugasnya. Untuk mengetahui secara pasti, adanya pengaruh tidak signifikan, perlu adanya penelitian lebih mendalam. Berdasarkan fakta di lapangan, terdapat perbedaan persepsi antara guru dan kepala sekolah tentang kinerja guru, perbedaan ini diduga menjadi sebab bahwa motivasi berpengaruh tidak signifikan terhadap kinerja guru. Pencapaian kinerja menurut presepsi guru, merupakan pencapaian 4 (empat) kompetensi dasar sebagai pendidik yaitu kompeteni kepribadian, pedagogic, profesional, dan social. Sedangkan presepsi Kepala Sekolah sebagai pemimpin, kinerja guru merupakan segala bentuk kepatuhan dan loyalitas terhadap Kepala Sekolah. Guru yang memiliki potensi tinggi dan memenuhi kompetensi dasar guru, tidak ada nilainya di hadapan Kepala Sekolah jika guru tidak patuh dan tunduk terhadap kehendaknya. Hal ini dapat ditunjukan oleh nilai SKP (Sasaran Kinerja Pegawai), dimana guru yang memiliki potensi dan sudah memenuhi kompetensi dasar, mendapat nilai SKP lebih rendah dibanding guru yang tidak memiliki potensi dan tidak memenuhi kompetensi, tetapi patuh dan selalu tunduk pada perintah kepala Sekolah. Adanya pemahaman antara guru dan Kepala sekolah yang tidak sinergi, maka hal ini menjadi penyebab penelitian ini menemukan bahwa motivasi berpengaruh tetapi tidak signifikan terhadap kinerja guru.

Vroom dalam Mulyasa (2011), mengemukakan bahwa kinerja seseorang merupakan fungsi perkalian antara kemampuan (ability) dan motivasi (motivation), secara matematis dapat ditulis: Performanc $=$ Capability $\times$ Motivation . Berdasarkan teori Vroom dan hasil penelitian, dapat dianalisa bahwa motivasi yang berpengaruh tetapi tidak signifikan, dapat disebabkan oleh kemampuan yang sangat mempengaruhi kinerja guru, sehingga motivasi menjadi berpengaruh tidak signifikan terhadap kinerja guru. Hal ini didukung oleh temuan Englasari (2017), yang mengungkapkan bahwa kinerja merupakan kemampuan (capability) yang dimiliki guru dibidangnya, dengan kemampuan tinggi di bidang pembelajaran, maka motivasi berpengearuh tidak signifikan terhadap kinerja guru. Sesuai teori Vroom, moivasi yang tinggi yang dikalikan dengan kemampuan yang tinggi akan menghasilkan kinerja yang tinggi pula. 
Hal ini dapat diupayakan melalui menyamakan presepsi tentang kinerja guru bagi seluruh unsur pendidikan, terutama Kepala Sekolah dan guru. Berdasarkan hasil penelitian yang diperkuat penelitian terdahulu dan teori yang mendukung, serta hasil analisis, motivasi memiliki pengaruh positif tetapi tidak signifikan, maka Ha3 ditolak.

\section{Pengaruh Kepuasan Kerja (X4) terhadap Kinerja Guru (Y)}

Kepuasan kerja guru berpengaruh positif dan signifikan terhadap kinerja guru. Hasil penelitian ini sejalan dengan hasil penelitian terdahulu yang dilakukan oleh Poerwaningrum \& Sudirjo (2016) dengan judul "Pengaruh Kepemimpinan, Budaya orgaanisasi, Komitmen Organisasi dan Kepuasan Kerja terhadap Kinerja Guru SD Hj. Isriati Baiturrahman I Semarang”. Begitu juga hasil penelitian Fatati dkk (2019) bahwa kepuasan kerja berpengaruh positif dan signifikan terhadap kinerja.

Bardasarkan hasil penelitian, tanggapan responden terhadap masing-masing pernyataan, dapat disimpulkan bahwa kepuasan kerja guru di Sekolah Dasar Negeri gugus IV Kecamatan Tampan Kota Pekanbaru dapat dikatakan belum baik. Pemerintah dan Kepala Sekolah seharusnya selalu berusaha untuk memenuhi kepuasan kerja guru dalam rangka meningkatkan kinerja guru, hal ini terutama dalam hal bebas menentukan cara sendiri menyelesaikan tugas, mendapat kesempatan yang sama dan adil dalam promosi jabatan dan kenaikan pangkat, adanya saling tolong menolong dan memberi dukungan antara warga sekolah. Kepuasan kerja adalah ungkapan perasan guru terhadap segala sesuatu yang mendukung kerja dalam rangka peningkatan kinerja guru (Kamdron, Raziq \& Maulabakhsh). Kepuasan kerja guru dapat tercapai dengan cara pemenuhan kebutuhan melaui dimensi gaji dan tunjangan, dimensi ini menyatakan kepuasan terhadap gaji dan tunjangan maupun insentif yang diterima, beban pekerjaan tidak memberatkan, adanya kesempatan pengembangan karir, adanya supervisi dari Kepala Sekolah secara berkala, serta adanya rasa sosial yang tinggi dari kerabat kerja dan kepala sekolah (Shabir \& Wei, 2015). Berdasarkan hasil penelitian yang diperkuat penelitian terdahulu serta teori yang mendukung, maka Ha4 diterima.

\section{b. Uji simultan (Uji F)}

Uji F menunjukkan pengaruh seluruh variabel independen secaara bersama-sama terhadap variabel dependen. Hasil uji F disajikan dalam tabel 4.

Tabel 4. UJi F (Simultan)

\begin{tabular}{|ll|l|l|l|l|l|}
\hline Model & & Sum of Squares & df & Mean Square & F & Sig. \\
\hline 1 & Regression & 6.332 & 4 & 1.583 & 52.821 & $.000 \mathrm{~b}$ \\
& Residual & 1.798 & 60 & .030 & & \\
& Total & 8.131 & 64 & & & \\
\hline
\end{tabular}

Sumber: Olahan Data Primer

Berdasarkan tabel 4 diperoleh informasi bahwa seluruh variabel bebas secara bersama-sama berpengaruh positif dan signifikan terhadap kinerja guru.

Berdasarkan hasil penelitian ini, ditemukan bahwa kinerja guru dapat meningkat apabila kepemimpinan dijalankan sesuai dengan prinsip-prinsip kepemimpinan mencakup kemampuan pendidikan, personal, relasional, intelektual, dan kemampuan organisasional. Kemudian iklim organisasi sudah kondusif yang dilihat dari dimensi 
tanggung jawab, adanya kehangatan hubungan kekeluargaan di organisasi sekolah, tidak adanya konflik, dan adanya imbalan yang sepadan serta adanya sanksi yang sifatnya membangun bagi guru yang tidak melaksanakan tanggung jawabnya. Kinerja guru juga dapat ditingkatkan dengan adanya motivasi yang tinggi yaitu terpenuhi faktor fisiologi, adanya rasa aman, kebutuhan social yang terpenuhi, adanya penghargaan dari pimpinan dan sekolah serta adanya aktualisasi diri guru. Kepuasan kerja juga memiliki pengaruh yang signifikan dalam meningkatkan kinerja guru yaitu terpenuhi gaji dan tunjangan, sifat pekerjaan yang sesuai dengan kompetensi guru, adanya kesempatan pengembangan karir, adanya supervisi secara berkala, kerabat kerja selalu mendukung, serta lingkungan kerja yang menyenangkan. Berdasarkan hasil penelitian yang diperkuat penelitian terdahulu serta teori yang mendukung, maka Ha5 diterima.

\section{c. Uji Koefesien Adjusted $R$ Square}

Besarnya pengaruh variabel Independen lebih dari 1 (satu) terhadap Variabel dependen dapat diketahui melalui nilai Adjusted $R$ Square pada tabel 4.21.

Tabel 5. Besarnya Pengaruh Variabel Independen terhadap Variabel Dependen Model Summary ${ }^{\mathrm{b}}$

\begin{tabular}{|c|c|c|c|c|c|c|c|}
\hline \multirow[t]{2}{*}{ Model } & \multirow[t]{2}{*}{$\mathrm{R}$} & \multirow[t]{2}{*}{ R Square } & \multirow{2}{*}{$\begin{array}{l}\text { Adjusted } \\
\text { R Square }\end{array}$} & \multicolumn{4}{|c|}{ Std. Error of Change Statistics } \\
\hline & & & & the Estimate & R Square Change & F Change & df1 \\
\hline 1 & $.883^{\mathrm{a}}$ & .779 & .764 & .17312 & .779 & 52.821 & 4 \\
\hline
\end{tabular}

Sumber: Data Primer Olahan SPSS

Berdasarkan tabel 5, diperoleh nilai Adjusted $R$ Square tinggi, yang berarti kepemimpinan, iklim organisasi, motivasi, dan kepuasan kerja secara bersama-sama berpengaruh kuat sebesar 76,4\% terhadap kinerja guru, dan sisanya sebesar 23,6\% dipengaruhi faktor lain yang tidak dibahas dalam penelitian ini.

\section{KESIMPULAN}

Berdasarkan hasil penelitian dan pembahasan yang telah diuraikan, maka kesimpulannya dapat dinyatakan bahwa terdapat pengaruh positif dan signifikan kepemimpinan, iklim organisasi, kepuasan kerja terhadap kinerja guru Sekolah Dasar Negeri gugus IV Kecamatan Tampan Kota Pekanbaru baik secara parsial maupun simultan. Sedangkan motivasi berpengaruh positif tetapi tidak signifikan terhadap kinerja guru secara parsial, namun secara simultan berpengaruh positif dan signifikan. Bertolak pada temuan ini, dapat dinyatakan bahwa motivasi guru yang baik, tidak dapat menjamin bahwa kinerja guru menjadi tinggi, tetapi dengan dibarengi kemampuan guru yang baik, pengaruh kepemimpinan, iklim organisasi, kepuasan kerja yang terpenihi, maka dapat meningkatkan kinerja guru.

\section{SARAN}

Berdasarkan hasil penelitian, dapat dibuat saran-saran dengan tujuan perbaikan dan penyempurnaan. (1) Kepada pemerintah hendaknya memfasilitasi kegiatan-kegiatan dalam rangka meningkatkan kinerja guru, (2) Dinas Pendidikan hendaknya menyatukan presepsi yang sama bagi seluruh unsur pendidikan tentang kinerja guru agar kebijakan yang diambil dapat meningkatkan kinerja guru dalam rangka mencapai tujuan pendidikan Nasional. (3) Kepala Sekolah dan tata kelola sekolah agar meningkatkan 
kemampuan kepemimpinannya, menciptakan iklim organisai yang kondusif, senantiasa memberi motivasi kepada guru, memenuhi kepuasan kerja guru dan menyamakan presepsi tentang kinerja yang akan dicapai sehingga kinerja guru dapat meningkat. (4) Bagi guru disarankan untuk tetap meningkatkan motivasi dan selalu meningkatkan kemampuan diri sebagai kompetensi dasar guru agar kinerja guru terus meningkat agar kualitas pendidikan di Indonesia terus meningkat. (5) Bagi peneliti selanjutnya agar dapat melakukan penelitian mendalam bahwa motivasi memiliki pengaruh yang tidak signifikan terhadap kinerja guru.

\section{DAFTAR PUSTAKA}

Depdiknas, R.I. (2003). Undang-undang RI No. 20 tahun 2003 tentang Sistem Pendidikan Nasional. Jakarta: depdiknas.

Englasari, (2017). Pengaruh kemampuan manajerial dan kingkungan serta motivasi terhadap kinerja guru SMA Negeri di Musi Banyuasin. Jurnal Ilmu Manajemen, 6(2), 127-139.

Fadhli, M. (2017). Manajemen peningkatan mutu pendidikan, Jurnal Studi Manajemen Pendidikan, vol. 1, No. 2, 215-240.

Fataati, M. A., Tobing, D. S. \& Hana, S. W. (2019). Pengaruh kepuasan kerja, dukungan organisasi, dan motivasi kerja terhadap kinerja guru SMK swasta di Kecamatan Sumbersari. Jurnal Ekonomi. Vol. 13, No. 2, 271-294.

Ghozali, I. (2018). Aplikasi Anlisis Multivariat dengan Program IBM SPSS 25. Semarang: Badan Penerbit Universitas Diponegoro.

Han, J. \& Yin, H. (2016). Teacher motivation: definition, research development and implications for teachers. Cogent Education, vol. 3, No.1,1-18. https://doi.org/10.1080/2331186X.2016.1217819

Husna, R. N. (2019). Pengaruh kepemimpinan, iklim organisasi, dan motivasi kerja terhadap kinerja guru di yayasan Al-Huda. Jurnal Eko dan Bisnis, Vol. 10, No. 2, 273-278.

Irawati, Sudarno, \& Komardi, D. (2019). Effect of Work Motivation, Organizational Culture on Work Satisfaction and Performance of Teachers in Public Junior High School Pekanbaru. Jurnal Ilmiah Manajemen, 7(2), 210-221.

Kamdron, T. (2015). Work motivation: Relationships with job satisfaction, locus of control and motivation orientation. International Journal of Liberal Arts and Social Science, 3(6), 125-148. Retrieved from https: //pdfs.semanticscholar.org/846c/9ad06718dc9f87da9269642808d3baa8d171.pdf

Kamuli, S. (2012). Pengaruh iklim organisasi terhadap produktivitas kerja pegawai Sekretariat Daerah Kota Gorontalo. Jurnal Inovasi, 9(1), 1-8.

Maeni, M. (2018). Hubungan antara motivasi berprestasi dan kepuasan kerja dengan kinerja guru Sekolah Dasar di gugus 4 Kecamatan Cikulur Kabupaten Lebak. Jakarta: Tugas Akhir Program Magister, Magister Pendidikan Dasar Universitas Terbuka.

Markonah, S. \& Sunarto. (2018). Pengaruh Motivasi dan kompetensi terhadap kinerja guru dimediasi komitmen organisasional (studi kasus di SMAN 1 Jakenan Pati). Mahasiswa Pasca Sarjana Stikubank, 1(1), 1-8.

Muizu, W. O. Z., Kaltum, U. \& Sule, E. T. (2019). Pengaruh kepemimpinan terhadap kinerja karyawan. Perwira. Vol.2, No.1, 62-78. 
Mulyasa (2011). Manajemen dan Kepemimpinan Kepala Sekolah. Jakarta: Bumi Aksara.

Poerwaningrum, H. E. \& Sudirjo, F. (2016). Pengaruh kepemimpinan, budaya organisasi, komitmen organisasi dan kepuasan kerja terhadap kinerja (Studi pada Guru SD. Hj Isriati Baiturrahman I Semarang). Jurnal Ilmiah UNTAG Semarang, $5(1), 1-14$.

Putra, R., Ernila, Komardi, D. \& Suyono. (2019). Pengaruh gaya kepemimpinan, motivasi, dan budaya organisasi terhadap kepuasan kerja dan kinerja guru pada SMKN 4 Pekanbaru. Jurnal Ilmiah Manajemen, 7(4), 470-483.

Qodriah, S. L. \& Muhsin. A. (2019. Pengaruh kepemimpinan kepala sekolah terhadap kinerja pasca promosi (studi kasus di Kabupaten Cirebon). Jurnal Manajemen dan Akuntansi, Volume XIV, No. 1, 184-192.

Raziq, A. \& Maulabakhsh, R. (2015). Impact of working environment on job satisfaction. Procedia Economics and Finance, 717-725. https://doi.org/10.1016/s2212-5671(15)00524-9

Risamasu, J. H. (2017). Implementasi dimensi kepemimpinan Kepala Sekolah di SMA Negeri I Obaa Kabupaten Mappi. MAPENDIK-Magister Manajemen Pendidikan Uncen, 04(01), 137-151.

Saragih, M. R. (2015). Pengaruh budaya organisasi, kompetensi guru dan motivasi terhadap kinerja guru SDN Joglo 05 Pagi Jakarta. Inovasi: Jurnal Ilmiah Ilmu Manajemen, 45-59.

Shabbir, M. \& Wei, S. (2015). Job satisfaction variance among public and private school teachers, case of Pakistan Administrative Kashmir. Mediterranean. Journal of Social Sciences, 6(4S1), 574-583. https://doi.org/10.5901/mjss.2015.v6n4s1p574

Steinberg, M. P. \& Garrett, R. (2015). Classroom composition and measured teacher performance: What do teacher observation scores really measure? Educational Evaluation and Policy Analysis, 38(2), 293-317. https://doi.org/10.3102/0162373715616249

Suwantono, A., Indrawati, M. \& Hidayat. (2019). Analisis kompetensi guru dan iklim o rganisasi terhadap kinerja guru melalui semangat kerja di SMK Negeri 2 Bojonegoro. e- Jurnal Mitra Pendidikan, 3(5), 670-685.

Wardoyo, T. (2018). Kontribusi Kepemimpinan Transformasional, Iklim Organisasi Sekolah, dan Motivasi Berprestasi Terhadap Kinerja Guru SDN Gembangan kecamatan Sentolo Kulon Progo. Media Manajemen Pendidikan, 1(2), 194-205. 